特集

\title{
風 合いの計測システム
}

\section{1. 風合いの判定は本来客観的な判断である}

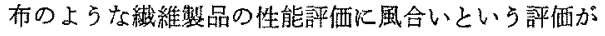
広く行なわれている。これらの整品はわれわれ人間が着 用乙，直接手に触れるのであるから，手で触れることか ら受ける感触による評価が，直接的な性能評洒であるこ と間違いはない。しかし，一見，純官能的火みえるこ の判定も詳しく解析すると種々の問題をはらんでいるこ とがわかる。ます第一に，われわれはたと就画を鑑 賞するのと同じ意味で感触の良さを評価しているわけで はないこと、—ここに風合いがかなりの実用性能を基 盤とする評価であるうと思われる理由がある。このこと は，絵画は鑑賞物で荡って特別な場合を除き実用的性格 をるたないのに対し，布は現代の生活でも依然として㬰 用品であり，その物理的な性能が着用性能を支配するこ 上から予想される。事实，われわれが，たと文怗消鿓者 の立場に立って服地を購入する祭, 必ずと言ってよいと 思らが布を手で触り，なんらかる判断している。そして この「なんらかの判断」には着たときの快適さ, 着やす さがかなりの成分として評価伅わっていることは経験 するところである。

こらしたことを考光ると風合いの判定には経験が要求 されることがわかるであらら。手触りでは良かったが着 てみてるやはり良かったあるいは「しまった」と思う 释験の集積が日常生活に括いて各個人が風合いの判定基 隼をそれぞれ自分自身でつくり上げているのであるう。

しかしながら、このよ5にわれわれが自分自身の着る 衣服のために風合い判定をしているのとは別に，織維工 業炕掊いて衣服用の布を製造し加工する人達は，自分自 身の着用のためでなく，消費者を代表して上茺した判断 を布にくださねばならず，このとき判定者の個人の強い 好文が判断仂加ってはならないこは当然である。こ れが、これまで行なるれてきている風合いの判定が官能

Measuring System of Fabric Handle SUEO KAWABATA

京都大学工学部高分子化学教室 助教授・工博
川端 季雄

断ではあるが客钼的評価の性格をるつゆえんであると 思机る。

\section{2.「風合いとは何か」についての仮説}

すでに筆者が数年前に提出した仮説1,2)であるが，内

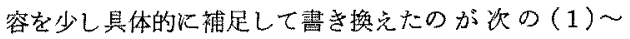
(5)の仅説でする。

風合いといら言葉が使われたり，その判定が行なわれ 吕材料に関して，

$\left[\begin{array}{l}\text { 使用に際して (a)直接その材料を身 } \\ \text { につけるか，あるいは身につけなくと } \\ \text { す（b）手足に触れる機会の多い用途 } \\ \text { の材料に执いて風合いが間題にされ } \\ \text { る。 }\end{array}\right.$

(仮説 1)

办服村料はこの（a)，(b)いずれにも該当するから， もち万ん風合いが重要な判定対象となっているが，たと えば，が゙ん材料としてのゴムなと，身炕つなが手 足に触れる機会の多い用途であるから(b)該当し，風 合いが問題にされる。

次に，風合いとしていかなる性質を測定しているのか という点について，手で触れたり，握ったりする判定操 作からわかるように，

(材料の力学的性質が判定の主たる詨象

(仅説 2 )

である。

たとえぱ，布の吸湿性や保温性は風合いの判定に関係 するよらで多るが，判定当事者恃手触りでそらした判 定はできないし，また行なっていないと言うす。これら は着心地（すなわち着用時の機能性）と関保する性質で あるが，着心地は必ずしす風合いのみとは関係していな いことに注意すべきである。

風合いの定籍やその判定基淮を明らかにするために は，誰れが風合いの真の判定者であるかを定めることは 重要である。この点について，

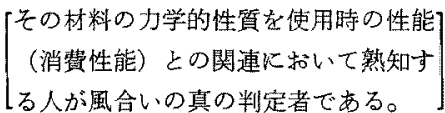
(仮説 3 ) 


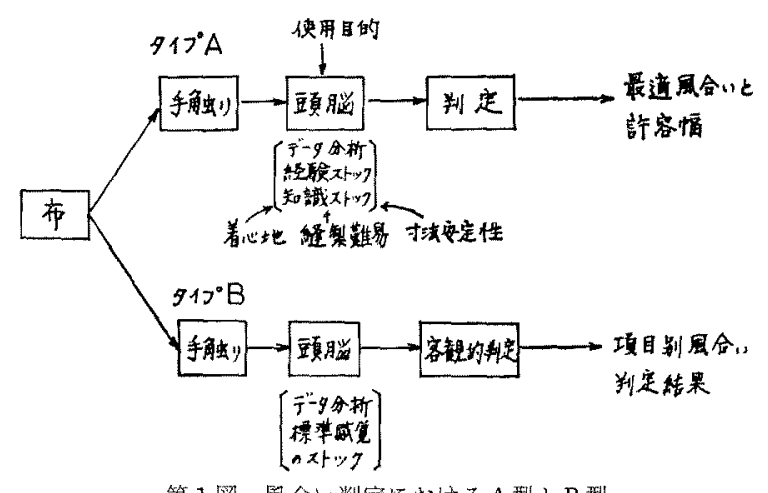

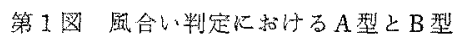

判定者には2つの型がある。

A型：真の判定ができる人

$\mathrm{B}$ 型：AからBへ，またはBからBへの伝详で判断法 学九た人

布の機能的性質の研究が非常に立掘れている今日，瀻維 工業に轵いて風合い判定に徤事する人はB型に属する人 が注とえどといってょいであるう。しかし，Aに近い人 もかなり存在するはずで，縫製を專門とする技術者など が比較的Aに近いと思われるが，いずれにせ上完全なA 型の人性実在せず，理念的存在で苏っても善支えがない。

ここで流涌の最徯は消費者であるから，消費者がA型 であるらとする「消費者は王梯」的考学が市る。しかし， これについては，始めに过述べたが経験の䦌題がある。 すなわり一般の消費者が各種の布を使用して比䡆し, 経 験を集䅡した仮説 3 の条件を泗たす人とは孝えられない からで妿。

布の風合い判定者住，前相したよらに手触りといら方

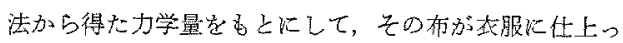
たときの，型くすれれの乙難さ(寸法安定性)，着心地の

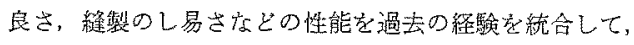
頭脳しいう計算システムで短時間に喵算していると考觉 てよいであるう。こうした考えから判定の基準関して， 仮説 3 より次が尊かれる。

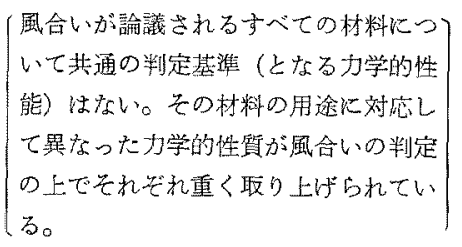

仮説 4は生た次の上らにも裴現できる。 $\left[\begin{array}{l}\text { 村料の用途に応して，それに邀合しだ } \\ \text { 力学的性質を有するかとうかが，その } \\ \text { 風合いの良否を決める。 }\end{array}\right]$

(仮説 $4^{\prime}$ )
最後火以上の仮説から炏のよ5に風合いが定 義される。

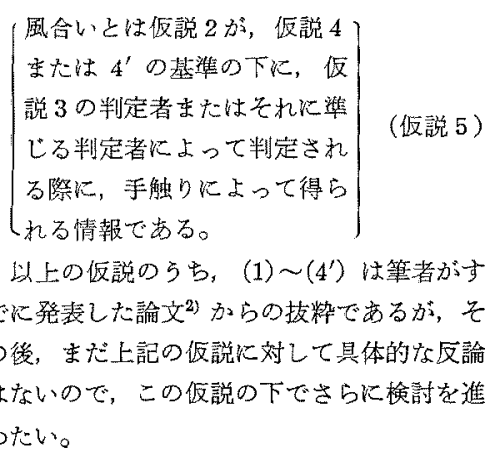

3.「風合い」「良い風合い」「好きな風合い」 「好み」「流行」などの区別

表題に列学した言葉が，とき混间されて同意に用い られることがあるが，明確な区別をして战く必要があ る。仮説 4'に適合するような「性貿」は消費者の個人 差户，用途の描の広がりもあって，㐫る幅を持つである う。この「性㗨」はまた，らつらは後述するように数項 目份解されているが，それ艺れが，したがって幅を持 つことになる。亜い風合いとはこうした幅から，いずれ かの項目が外れているときに用いられる。そらでない場 合は良い風合いである。良い風合いとは最適の風合いと いう意味ではない。

また，各項目の幅の中で，それぞれの適当な組み合わ

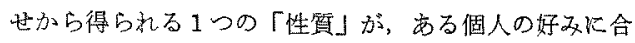
致するとき，その「性質」はその固人にとって「好きな 風合い」と表現される。また，「流行」は個人の好无が 筑行の流れに影響されているとき，各人の平均犆的好双 以痛差が生じることを言うのであるらが, 本来, 風合い とは然閶係であると思ら。

ここで注意すべきは，ふつう消費者に「好み」の調查

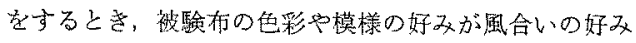
と混同されることである。この分離がなされないと，好 きな根い好きな風合いへと移行して風合いの意跦が準乱 するるととなる。

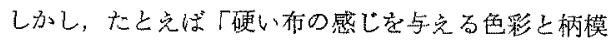
様」といらょらな場合，色彩が，手触りから得られる力

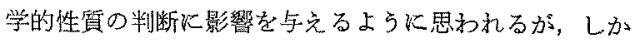
し「見た感じと着た感じは基なる」范るいは「見た感じ と触った感じは異なる」ということにもなり，風合いの

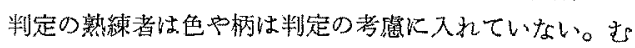
しろそらしたものに影響を受けてはならないといわれ 尚。 
倜人にあける柿の连択

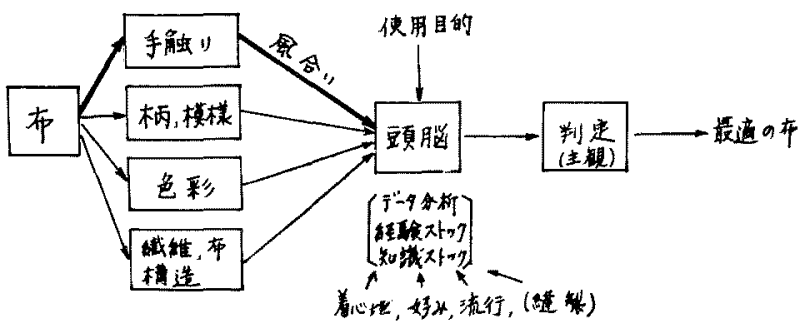

第 2 图消費者に特汁各布の選択
る゙っ。をた 「body が饬る」とは，手に してみてなんとなく㧤害感のあること。 また \#9は視覚による锶察であって，こ 和峙色彩が美しいといら意味でなく，色 が明確に布表面に現和れる感じで，布の 表面形状瀑倠される。こ祅は風合いと 他の判定との境界領域の判定と考学てよ

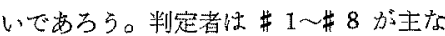
判定であることを述べている゙)。 \#8 K ついては後述する。

以上の項目のみ文名々，感覚的表現 が強い印象を受けるが，しかし，各項目 について，たと党ば「奴り」を例浅すると，第 3 四に 示すように，功り精密な判断がなされている。ここで は紿対值表示をとっているが，現場では風合い見本との 対比で判断されていることも多い。

ここで注意すべきは，この精密な判定が仮説 3 の判定 者によって行なわれるときこの精密さに意昧がある が，B型の人に上って客観的な品質評価として行なわれ ているときは，この精密な判定の差が，衣服として着用 するときにどの上らな差となっているのか判定者自身が 知らないようで西るが。このように現在，風合いの判定 はか外り客微的判断の性格をもつに至っているように思 われる。

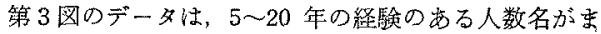
ボランクをつけ，最後に1人の熟練者が絶対值スケール へあてはめ大例である。ランクをつける場合の個人差 は，大体ランクが1段または 2 段入机換る程度である。 また同一会社内でる工場の差がやや認められるという。 すなわり平常，男子用衣服，婦人用有，合瀻なと，それ 艺机尃門に报っている人達住対して同一の男子用衣服を 判定させると，やはり誤差が生じる。たとえぱ，婦人服 では「ぬめり」はそんなに過酷な判断の対象になってい ないので,こうした布を尃門化报ら人が男子用布を判定 すると「「めり」のランクの低いものむ高く評価する きらいがあるといら。これ性傥 4 の差が生じている例 第2 表 ASTM 方式風合い

\begin{tabular}{|c|c|c|c|}
\hline $\begin{array}{l}\text { 項目 } \\
\text { 番奇 }\end{array}$ & 項 & 内 & 容 \\
\hline$\# 1$ & Flexibility & pliable & $\leftrightarrow$ stiff \\
\hline$\# 2$ & Compressibility & soft & $\leftrightarrow$ hard \\
\hline$\# 3$ & Extensibility & stretchy & $\leftrightarrow$ non-stretchy \\
\hline$\# 4$ & Resilience & springy & $\longleftrightarrow \lim p$ \\
\hline$\# 5$ & Density & compact & $\leftrightarrow$ open \\
\hline$\# 6$ & Surface Contour & rough & $\longleftrightarrow$ smooth \\
\hline$\# 7$ & Surface Friction & harsh & $\longleftrightarrow$ slippery \\
\hline$\# 8$ & Thermal Character & warm & $\leftrightarrow \mathrm{coOl}$ \\
\hline
\end{tabular}


であると䍐う。

次化，ASTM 方式第2表に示している。この判定

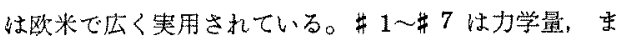
なは関連する性質で苛るが，\#8は仮説 2 から外机る例 外である。しかしこれは仮説 3 の判断のらら手触りで 判断がつく項目であるし，風合いの判定に加かったので あらう。また同じ羊毛緎維を対象にして（熱的性質に大 差はないはず） warm，cool が判断されることを考える と，これは手触りをと扣して対象物の幾何学的構造から くる効果の判定とも考光られる。あるいは，幾何学的形 状が些際に表面熱伝遒の性質を变化させることの效果が あるらから，こ机手船りで確めるのか子知れない。さ らにこ礼と相関の高い，布のやわらかさなどの力学量が

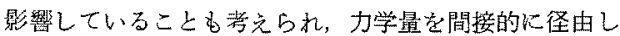
た手触りとい5点で，風合いであると考觉ると仅説 2 K も適合することになる。

ASTM 万式は，基本力学量々のものが項目になって いるのが多い。前述の日本式と比較すると，やや人間味 の薄い客観的な表現であるが，大きな特幑は，項目相互 間の干涉が少ない点に范る。これは，西欧語のるつ科学 的で明確な表現によるところが大きいのであるう。この ことが人間の感覚表現を分析的にしているものと思われ 吉。

たと总ば、日本語で硬い」(⿻1 項目)という語は， 第 3 表に示すように英語では stiff，hardなと，別の語 のいくつかに分解さ机ている。日本方式に执いても，「硬 い」といら表現には ASTM 方式の如き各種のかたさが 嗏知されているのであっで，ASTM 方式の区别が判定 持になされているるのと思われるが，それが頭の中で整 理され直観的に硬いといら語の表現に生れ変るので，風 台いが理解し難い（未訓練者にとって）手のになってい るといえよう。

しかし，以上述べた両方式は，いずれも比較的精度上 く，客観化された判断ができるよらに，必要最小限に判 定項目を制限している。このような風台いが尃門家の風

第3表 日本式とASTM 方式の比較

\begin{tabular}{|c|c|}
\hline 日本式（日体語） & ASTM 式 (英嘼) \\
\hline 硬い〜や加らかい二 & $\begin{array}{l}\rightarrow \text { stiff〜pliable (Flexibility) } \\
\text { 曲げかたい } \\
\rightarrow \text { hard〜soft (Compressibility) } \\
\text { 押えるとかたい } \\
\rightarrow \text { non-stretchy〜stretchy (Extensibility) } \\
\text { のびにくい } \\
\rightarrow \text { springy〜limp (Resilience) } \\
\text { 元気のあるかたさ，元気のないやわらかさ }\end{array}$ \\
\hline
\end{tabular}

合いである。

これに対して，こうした項目を知らず，たた感じたま まを，擬態語などで自由に表現するのが，素人の風合い である。たとえば，「硬い」「奴めりがある」「しゃり感 …‥という専門家の表現に対して，「ぎしぎしする」「ご わごわずる」……無数の表現が整理されず自由に使 われる。各個人では，これらの表現に対する解粕の相違 もあるらし, 表現力の不足もあ万らが，もし着心地の々 れも手触りに関係したり，变形特珄に関する特性の素現 であるならば，こ礼は風合いの表現である。しかて，そ らした表現は，専門家は前述の 8〜9 頊目のいずれが 適確にはめこんでいる。

\section{5. 布の物理量による風合いの数値化について}

以上述へたように，すでに現在，風合いの判定は宫能 試験ではあるがかなり客観化されているといらべきであ る。これを一歩進めて，仮説 2 を容認するとして，計測 器によって力学量を計測し，適当なデータ処理により風 合い表現の各項目について，判定結果を数値で表現し得 るならば，その精度は熟練した人間の行なら広籍で緎細 な判定に比較すれば恐らく低いであるうが，得られる利 点はむし万それを補って余りあるであるう。すなわら，

1. 判定者による個人差が解消する。

2. 定量的に䁏眜な判定結果が明確に数値化される。

3. 咘の性能々風合いの関䋆についての解析がやり易 くなる。たとえば着心地の研究が急速に進さだ う。きた風合いが数俌化されているならば，さらに 進んで布の性質の規格化が急速に進さであるう。

4. 标の構造と物性の関係を結ぶ理諭が最近著るしく 進歩したが，これを用いて風合いの設計や制御が可 能になる。すなわち，久しく織維工業で待望されて いた製品性能の設計を实現する大きな障害が除去さ れる。

ここで思い起すのは系もらの評価である。10 年以前 にはまだ一種の官能評価であるセりプレーン法が広く行 なわれていた。䇠者が学生だった頃 紡續工場にはセりプレーン检查室が あったのを思い出す。しかしその 頃から霞気式，空受式，機械式の各 種䧽さら陚駼機が競って開発され現 在は笔気式によまったよらである が，いつしかU\%しいら評洒值一も ら評価としては欠陷のある評值で虫 あるが一によるむら表示がセりプレ ソ法をいまや消し去ってし方った事 実がある。 

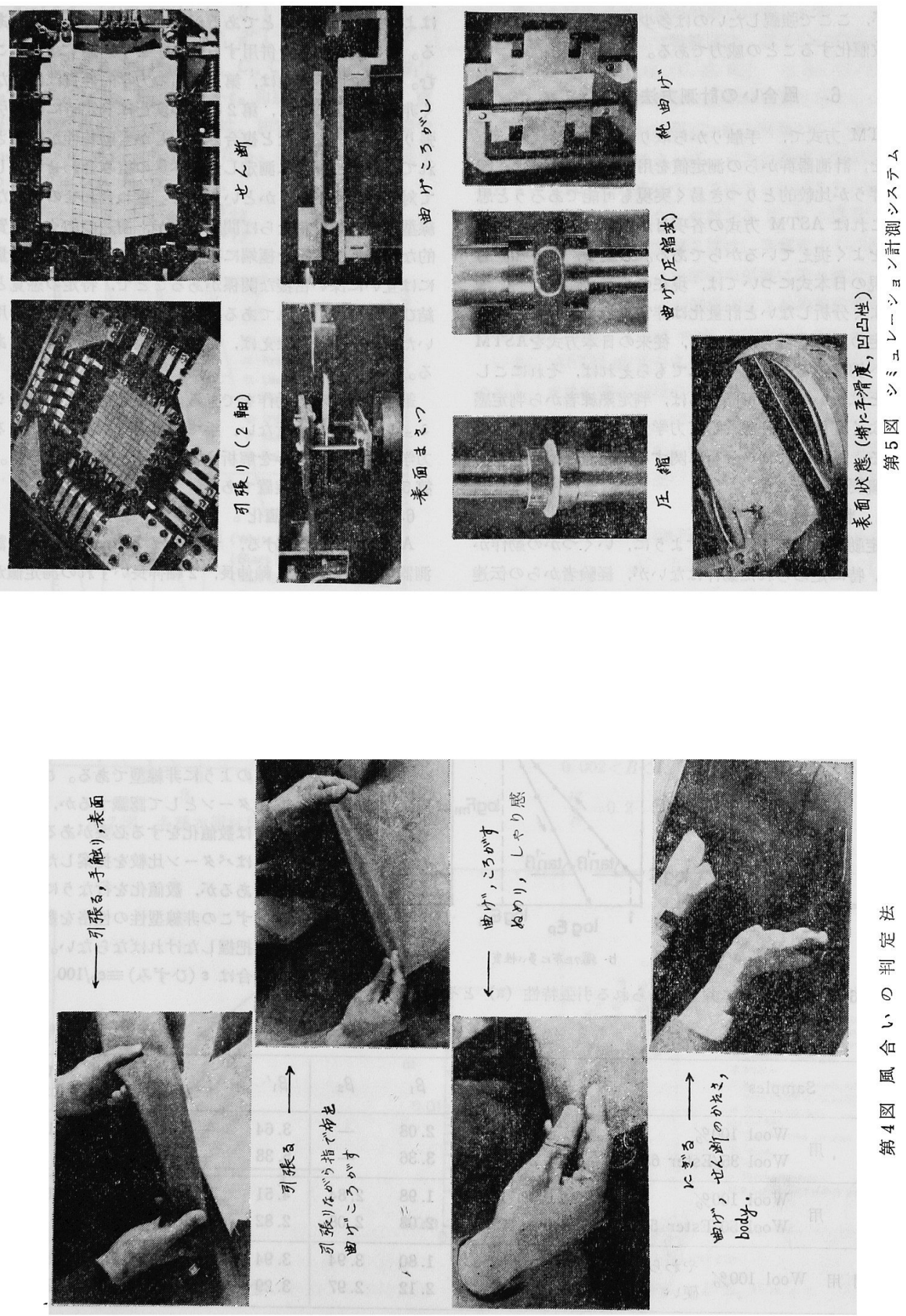


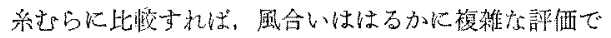
あるが、ここで強調したいのは多少不完全な評価であっ てる数俌化することの咸力である。

\section{6. 風合いの計測方法について}

ASTM 万式で，手触りから取り出している風合いの 情報を，計测器群がらの湘定䛧を用いて得ることは，困 難は伴らが比校的とりつ是易く实現も可能であるらと思 5。これは ASTM 方式の各項目が板状試料の基本的力

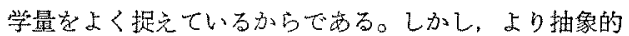
な表現の日本式については, 現在の判定動作や判断法 を，上く分析しないと計量化は非常化むずかしい。

判定の熟練者自身によって，從来の日本方式竟ASTM 万式へ切換觉る法揤を見出してもらえれば，それにこし たことはないが，不可能ならば，判定熟練者から判定感 覚をよく聞き出し, 並行して力学量の計測を行なら必要 がある。以下にこれら分析に関する問題点と筆者5の研 究の概要を述へよう。

\section{1 判定動作}

判定動作に恃第 4 図に示す上5に、いくつかの動作が 济る。特に定められた動作はないが，経駼者からの伝達 などにより，图に示した動作が日本では普通に行なわれ る。これらの動作から，さきさ9項目が判断される。

6.2 判定動作のシミュレーション

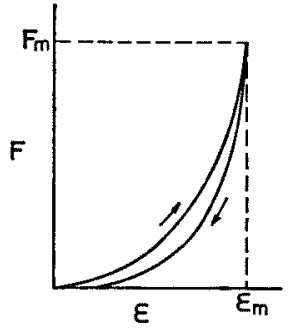

$a$

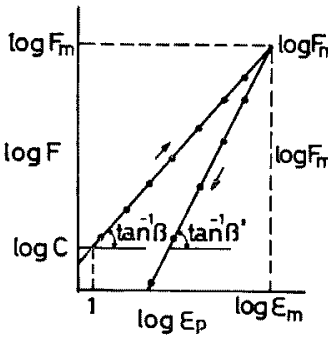

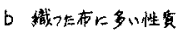

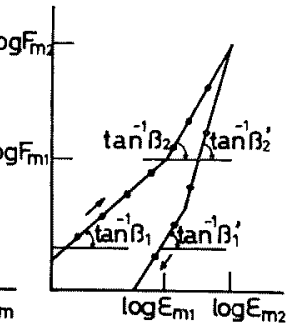

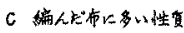

第 6 图衣服枋料火共通に双られる引張特性（a）とその值線化（b，c）
感覚ないきなり力学量上比敬し，その対応をとること はよく行なわれることであるが，非常に困難なことであ る。特烷計解析を併用するとますます迷路に落ちこ む。困難である理由は，第 1 亿布の力学的性質は例外な く非線型であること，第 2 に布の変形は判定時には，引 張り，曲げ，圧繀など複合され，乙かも動特性が検出さ れているが，個々に湘定した力学量の組み合わせで果し て対応がつくだろらかといらこと。重叔合わせの可能な 線型性のある材料ならば問題ないが，前述の如く，本質 的な非線型は問題を゙極端に複雑にする。第 3 K各力学量 には互いに深い嘧接な関係があることで，特定の憾覚と 結びっくのはいずれであるかる，単純に多変量解析を用 いた統計解析を行な兄ば，奇妙な結果が出ることるあ る。

笔者らは，判定動作をできるだけ単純化して，とのシ ミュレーションを行ない，手で判断するのは，いかなる 力学的性翼であるが解析することを亦ず進めている。 第5図は試作した装置でする。

\section{3 力学量の数値化}

ASTM 方式に括ける，たとえば Extensibility を棓 测器で得るとき， 1 軸伸長，2軸伸長いずれの測定值が より適確に表現し得るか，あるい恃両渚が必要かなと多 くの問題がある。筆者は 1 朝， 1 軸拘束 2 軸， 2 軸均等 の3形式の引張りが必要であると思う。もし一つで代表 させるならばあとの2者のいず れかであるら。

次比, 得られるデータ恃第 6 図 のようk非線型で岗る。これをパ ターンとして認識するか，もしく は数値化をする必要がある。筆者 はパターン比較を提案したことが あるが，数值化を行ならには，ま すこの非線型性の性格を数值的に 把握しなければならない。この場 合は $\varepsilon(ひ す ゙ み) ~ \equiv \varepsilon_{p} / 100$ として，

第 4 表 男用 Suits 織物

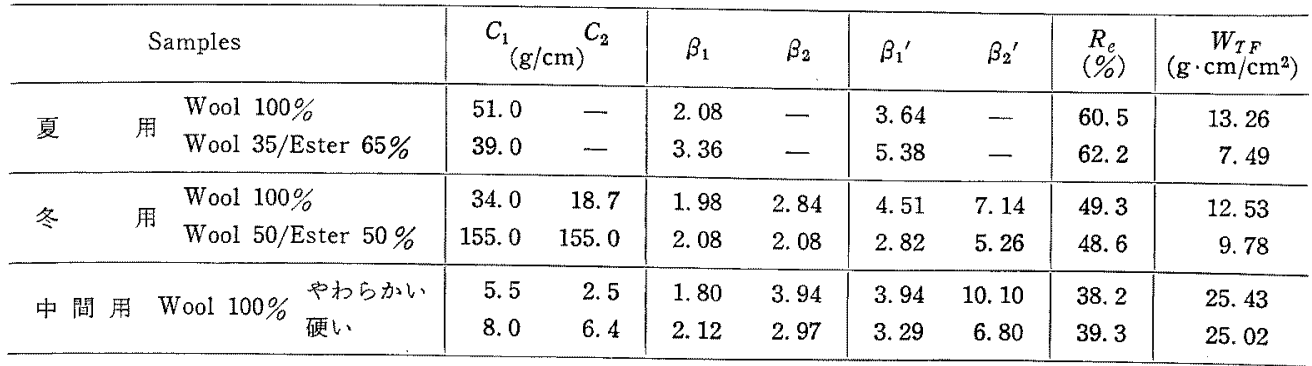


第 4 图上り次の関係式が上く適合する。

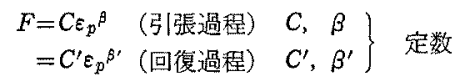

また折点がある場合は定数は， $C_{1}, C_{2}, \beta_{1}, \beta_{2}, C_{1}{ }^{\prime}, \beta_{1}{ }^{\prime}$ ， $C_{2}{ }^{\prime}, \beta_{2}{ }^{\prime}$ 飞なる。し加し， $F-\varepsilon_{p}$ 曲線の引返し点安, 直 線近似の交点にとると，定数怯，前者で $C, \beta, \beta^{\prime}$ 後者で $C_{1}, C_{2}, \beta_{1}, \beta_{2}, C_{1}{ }^{\prime}, \beta_{1}{ }^{\prime}, \beta_{2}{ }^{\prime}$ となる。この潘加源, 引張り のレジリェンス $R_{e}$ すなわち.

$$
R_{e}=\frac{W_{T B}}{W_{T F}}
$$

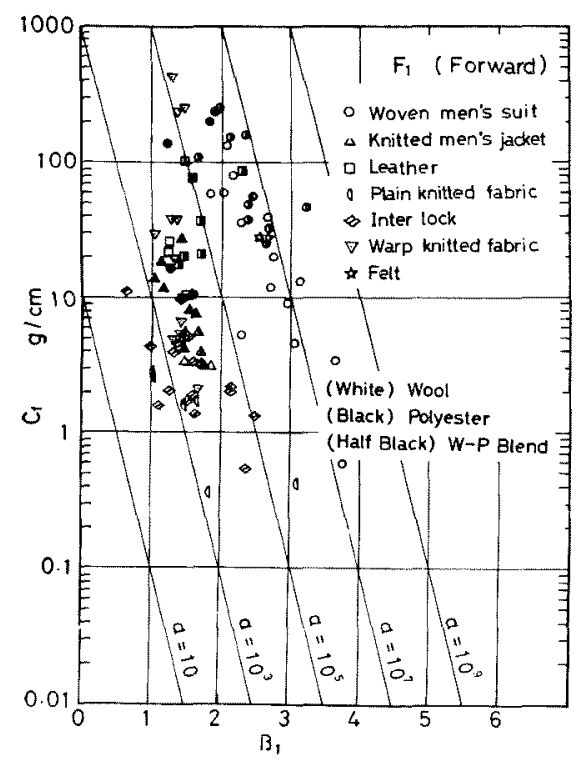

第 7 图 各種衣服材料の $C_{1}, \beta_{1}$

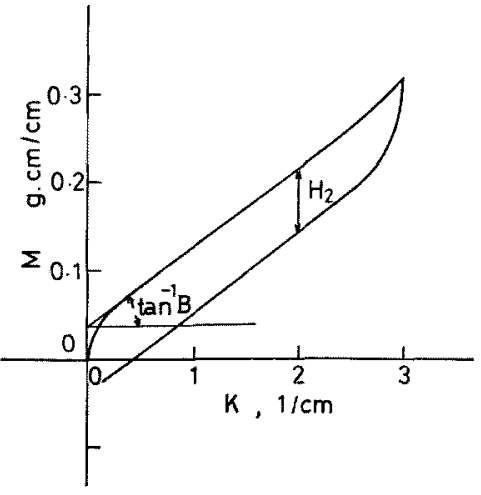

第 8 図曲 ザ特 性
$W_{T F}$ : 引張り過程に外部加ら布に加光た仕事

$W_{T B}$ : 回復過程儿市が外部入行なら仕事 も必要であるう。ここで特性值は，図 4 (b) の場合です，

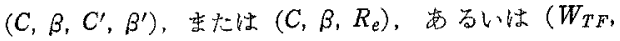
$\left.\beta, R_{e}\right)$ の組文合せが最少の必要特性值で范万う。地 $F_{m}$ 李たは $\varepsilon_{m}$ をいか心選ぶ加飞問題加生しる。現在 筆者の研㚾グループによって，この特性值の選択が進め られているか゚，この点とついてはをとて古らためて報 告したい。籍 4 表以風合いの罢なる 2,3 の織物のC, $\beta, R_{e}$ 值を示した。きた第 7 図は，各種布の $C_{1}$ 対 $\beta_{1}$ の 関係を示している。ここで図中の斜線は等 $\propto$ 線で，ここ で $\left.\alpha \equiv F\right|_{\varepsilon p=100}$ である。引張嵄式は2 軸均等引張りで， その warp 方向，㚘依 wale 万向を示している。

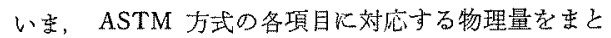
めると，まさとその表現の通りでする。しかし，前述の

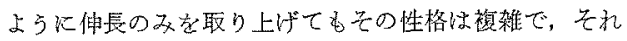

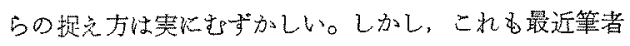
らのグループで矿究が進行しているので，近い将来，明 らか心され机。

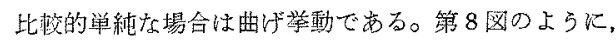
$M=B K \pm H / 2$

$M:$ 曲け゚ニーメント $K \cdot$ 曲率

$B$ : 曲げ揦性

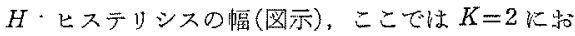
ける倠意とった。

として近似的に表わされる場合が多い。

らつら衣服として着用できる柿のB傎， $H$ 梴は

$0.002<B<1 \quad\left(\mathrm{~g} \cdot \mathrm{cm}^{2} / \mathrm{cm}\right)$

$\frac{H}{B}=0.2 \sim 5$

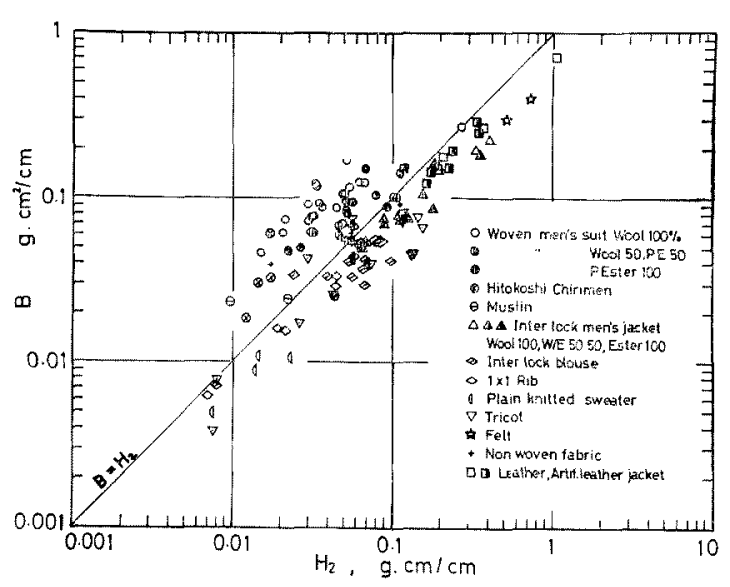

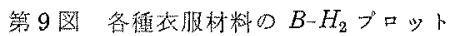




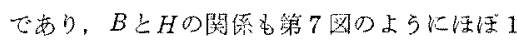

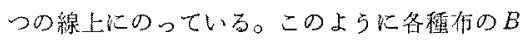

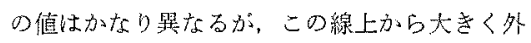
九た布はみられず，また用涂儿応して图中の特 定の位算老占めている。この図の示高閔係は力 学量の湘定值による風合い表示の可能䟶に希望 をもたる。

\section{7. 計測されたデータの処理}

計測されたデータはもらろん相互に強い相関 をるつ場合が多い。をこでこれらデータを風台— い評価值に变換するためには，たとえば多变量 解析手段に上り变换式が探られることになるで

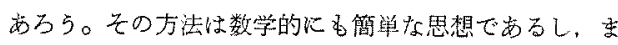
たコンピューターのたすけで計算も極めて容易である。 それより香間題はこうした解析に使ら。そして尗で述 ベたよらに複雑な性格をむつ物理量をいが適磼儿把む かといら点に古る。

この前提の下に，ななわらこの把握が適確であると作 定して，たとをば変撸式に線形モデルを用いると，

$$
\boldsymbol{H}=\boldsymbol{K} \boldsymbol{X}
$$

当な初量

$$
\left[\begin{array}{c}
\text { 硬さ } \\
\text { 張り } \\
\vdots \\
\vdots
\end{array}\right]=[\boldsymbol{K}]\left[\begin{array}{c}
C_{1} \\
\beta_{1} \\
\vdots \\
\vdots
\end{array}\right]
$$

風拿、 亲換マト 力学最

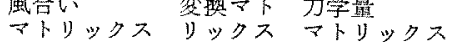

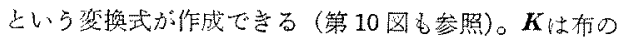

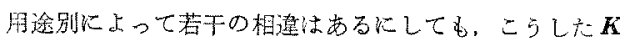
は存在すると䇥者らは考兑，現在この $\boldsymbol{K}$ 決定急いて

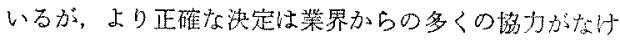
ればならないと思う。ここでは，Kの決め方に関しての

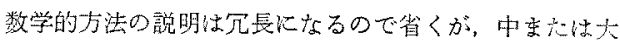
容量のコンピューターにより容易に行なるる。

(1)式加

$$
\boldsymbol{X}=\boldsymbol{K}^{-1} \boldsymbol{H}
$$

として風合いを与えて力学量 $\boldsymbol{X}$ が導ける。この逝算の

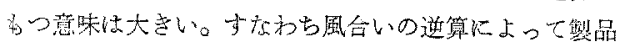
珄能設計入の一歩か゚炲等るからである。

\section{8. 風合いと織維特性との連結および} 今後の展望

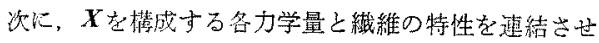

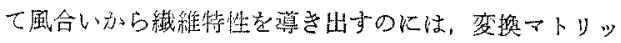
クスでなく，絊維集合体の力学を中心とする理諭が必要

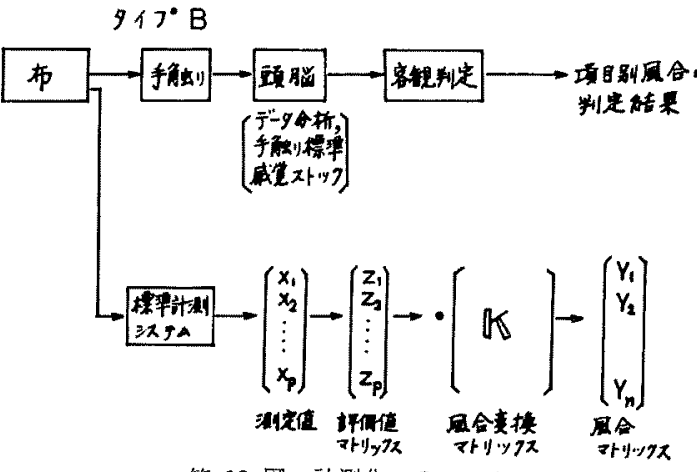

第 10 区 計測化へのルート

である。この理論も最近は急速に進歩しているので，風

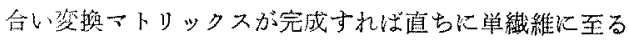
道が開通するであろう。ここに至って䋳維工策も職人の 工䍴から技術者の工業，椇言すれば設計技術に立脚した 近代工笔の一列に加わり得ることができる。さらに，わ

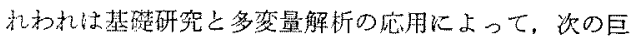
犬な、トリッス，

$$
P=\boldsymbol{T} Y
$$

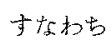

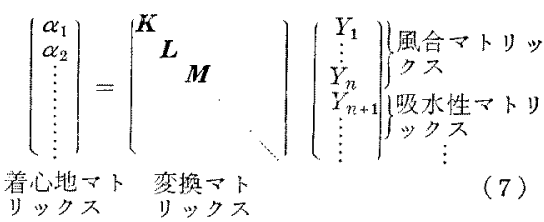

したがて

$$
Y=T^{-1} P
$$

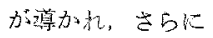

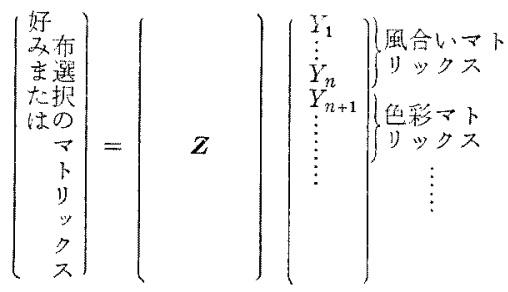

しいら活趺売上の有用なマトリッタスも尊かれよう。 またこの式によって筆者の主㖘する風台いの意昧が明確 に位置らけられると思ら。

\section{9. 計測システムの開発}

すでに述べてきた風合い計量では，むず力学量の棓测 が必要である。しかし現在，布などの集合体関保の計湘

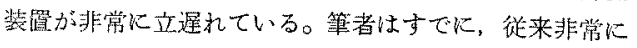


測定の困難であった曲げ陚駼機を完成し,さらに引張 り, せえ断, 王縮、粗さ，摩擦の陚検機の開発を進めて いる。こらした試験機が他にも多く製造されて，被維工 業に広く普及することが，何よりす風合い研究を現夷的 にさせる重要なことであるう。

なお，本文に用いたデーダ、，筆者の風合い研究グル ープのメンバーで, 共同研究者である奈良女子大学・丹 羽雅子氏，成安女子短大・七島陽子氏らの協力で採取さ れたもので，さらに風合い判定に協定いただいた䇺金與

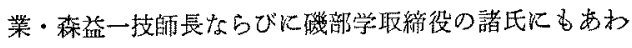
せて謝意を表したい。

文献

1）川端季雄; 第 16 回高分子夏期大学講演要旨篗, E 17 (1968)

2) 川端季赫；㵶維学会誌，25，191（1969）

3）䶕金與栄・椂益一氏との討論より

(雚和 47 年 3 月 24 日受盟)

\section{チェコスロバキアは化学工業の拡大をはかる}

Plastics, fibres and fertilizers lead

Czechoslovak chemical expansion

今後 10 年間比たる化学工業の生産抎張につい て, キェコスロメ゚キアは, 最近詳細なプランを発表し た。これは，プラスキック，繊維执よび肥料以関する 現在の生産基解を大幅強化拡大寸ることを的らった ものでめる。この扗張伴う原料ベースを確保するた めに, チェコスロバキアは原油供給を保護している。 これまでは，例外なくり連から原油供給を受けていた が，需要の增大火往ってイランからる榆入するように なってきている。チェコスロパキアに怙ける最近の化 学工業の動向は，ここ数年間にブラスチック，瀻維拉 よび肥料が急激に発展して括り，ブラスチック乱よび 合成樹脂の生産は，1980年要でに注約 3 倍に伸びる見 込で，これに伴う新プラント建設が計画されている。

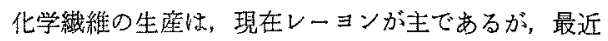
ポリアミドが急速に伸びつつある。今後 10 年間に合
成㵶維の生産は，4倍に堌強される計画で，1980年 には 110,000 t/年に蕫する予定で方る。肥料の分野で は，1969年に急激な增加がみられ，窒素肥料は $14 \%$ ， りん酸肥料は $9 \%$ 增を示した。こ札は家素と複合肥料 の生産改善によるもので，この㑯向は1980年まで続 くとみられている。カリ肥料は複合肥料として生産さ れているが，它の消費黨は前二者に比べてかなり大き く，大幅な增産が予定さ机ている。キェコスロパキア は，これをで化学繁品を大幅に渝入に賴ってきたが， これからは国内生産の增強によ。て輸入走減らし輸出 を拡大方る方針を打出した。かつて，東ヨーロッパ 化学工洋界飞大き位置を占めていだェコスロバキ アはここ 10 年間ずっと沈漰気味であった。新しく 示された 10 年計画のプランは，この情枩をなんとか 好転さよせらとするるのであるが，キェコスロバキア 6産業合理化と拡張の危機に直面しているとい方る。 表 1

H 422 Europe Chem. News 19 [477] 19 20(71)

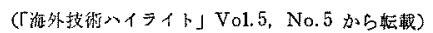

